\title{
Nocturnal insect pollinator diversity and species richness in Ridge gourd, Luffa acutangula
}

\author{
Archana H. Patil* \\ Department of Zoology, Dapoli Urban Bank Senior Science College, Dapoli, Ratnagiri-415713 \\ (Maharashtra), India \\ Sandesh Jagdale \\ Department of Zoology, Dapoli Urban Bank Senior Science College Dapoli, Ratnagiri- 415713 \\ (Maharashtra), India \\ *Corresponding author. Email: archanahpatil1@gmail.com
}

\section{Article Info}

https://doi.org/10.31018/ jans.v13i2.2625

Received: March 8, 2021

Revised: May 1, 2021

Accepted: May 6, 2021

\section{How to Cite}

Patil, A. H. and Jagdale, S. (2021). Nocturnal insect pollinator diversity and species richness in Ridge gourd, Luffa acutangula. Journal of Applied and Natural Science, 13(2), 463 - 469. https://doi.org/10.31018/jans.v13i2.2625

\begin{abstract}
Pollinators are rewarding for many wild and agricultural crop plants. The experiments were conducted in the agricultural field of Karad tehsil, Maharashtra, India. The present study concentrated on the diversity and species richness of nocturnal insect pollinators on Ridge gourd Luffa acutangula belonging to the family Cucurbitaceae. The Ridge gourd plant is monoecious with a bunch of male flowers and solitary female flower. Anthesis happened in late evening hours (17.00-19.00) and flowers remained for 13 to 14 hours. A total of 830 insect pollinators were sampled from June 2020 to November 2020. Altogether 17 species of insect pollinators belonging to 7 families under 6 orders were recorded. Among the total number of species, the Lepidoptera was the dominant order comprising 11 species belonging to the single family Crambidae followed by Blattodea comprising 2 species belonging to 2 families Ectobiidae and Blattidae. Hymenoptera comprised 1 species belonging to family Formicidae, followed by order Orthoptera comprising 1 species belonging to family Gryllidae, order Diptera comprising 1 species belonging to the family Culicidae, followed by the order Coleoptera comprising 1 species belonging to the family Chrysomelidae. The Diaphnia hyalinata belonging to family Crambidae of the order Lepidoptera was the most dominant species and was followed by Chabula acamasalis. The nocturnal species imparted pollination services to agricultural crops. The study also observed fundamental mechanisms of plant and nocturnal insect pollinator interaction as well as floral scent and visual signals. The study can be baseline data for conserving and managing the best pollinators for increasing the yield of Ridge gourd.
\end{abstract}

Keywords: Anthesis, Lepidoptera, Pollinator diversity, Ridge gourd, Species richness

\section{INTRODUCTION}

Cucurbits are a plant family consisting of about 965 species in around 95 genera (Christenhusz and Byng, 2016); the most important to humans are squash, pumpkin, ridge gourd, bitter gourd, watermelon, cucumber etc. Most of the plants in this family are annual creepers. Most cucurbits have imperfect flowers as the male and female reproductive parts are located in different flowers. Male flowers appear early and produce nectar and pollen; pollen viability in newly opened flowers is $92 \%$. Gradually, it gets reduced while female flowers appear later and produce more nectar and attract the insects. Most of the gourd flowers opens at night and usually last only one night (Nepi and Pacini 1993). The pollen grains of ridge gourd are large and sticky; therefore, it must be transferred from the anthers in male flowers to the stigma in female flowers, which is most often attained by diverse insect pollinators (Free, 1993; Delaplane and Mayer, 2000). The plant-pollinator relationship is considered as mutualism because as plant benefits from pollinator's transport of male gametes in return of nector. Flower visitation or pollen transfer by insects is frequently used as a proxy for insect-pollination (King et al., 2013). Thus the absence of these vectors would result in more than $95 \%$ fruit production loss in these crops (Klein et al., 2007).

Ridge gourd has many health benefits. It is rich in essential components like vitamin $A$ in the form of beta carotene, dietary fibers, water content, vitamin $\mathrm{C}$, iron, magnesium and abundant vitamin B6. It is naturally low 
in cholesterol, calorie content, and unhealthy saturated fats. Also, it is rich in antioxidants and alkaloid compounds, which regulate metabolism and eliminate toxins from the body, and thus it is an important vegetable crop. Being monoecious Ridge gourd have to crosspollinate and is dependent on other pollinating agents. Most studies to date have focused on diurnal pollinating insects, largely ignoring nocturnal insects The Ridge gourd flowers bloom in the evening, so nocturnal pollinators play a major role in pollinating the Ridge gourd (Subhakar and Sreedevi, 2015 ). The conservation and management of insect pollinators are gaining importance daily, so studies related to diversity, abundance, and species richness are essential. Hence the objective of present investigation was to generate information about the diversity, species richness of nocturnal pollinators of Ridge gourd,Luffa acutangula.

\section{MATERIALS AND METHODS}

The study was carried out on the agricultural fields of Karad tehsil Southern part of Indian state of Maharashtra. Karad is located at $17.28^{\circ} \mathrm{N} 74.2^{\circ} \mathrm{E}$. It has an average elevation of 566 metres (Fig. 1) with an average temperature of $29.1{ }^{\circ} \mathrm{C}$. Two different fields cropped with ridge gourd were selected. The fields were about 2023.428 square metres each at a distance of $3 \mathrm{Km}$. The study was conducted during peak flowering seasons from June to November 2020. At each site, we delimited $5 \times 5 \mathrm{~m}$ plots; 3 plots at each field for the survey of nocturnal pollinators.

Flower visitation by pollinators was observed twice in a week in the evening 19.00 to 22.00 . The number of insects visiting the ridge gourd flowers (only the insects touching the reproductive whorls of flowers) was also recorded and collected using the following modes.

- Portable light source

- Canon EOS 200 Camera: Photographs were taken and analysed for flower visitation

- Sweep net

After the photography and observation for visitation frequency, species were collected by sweeping with a sweep net. Insects collected through sweeping were transferred to plastic containers. The collected insects were sorted, labelled and preserved as dry pinned or preserved in $70 \%$ alcohol.

Hand collection

Some insect pollinators were collected by hand and transferred into killing bottles. The insects were processed for pinning and preserved on a wooden box in dry condition. The data were later averaged time wise to infer insect pollinators as well as species richness of a particular group.

The abundance of different insect pollinators of ridge gourd was studied during their blooming period. Randomly 20 flowers were selected. The total number of different insect visitors visiting on the number of gourd flowers in a square metre area was observed for two minutes per plant at an hourly interval from 19.00 to 22.00 hour using a stopwatch. The data was recorded for further analysis.

\section{Identification}

Insect pollinators collected were identified with the help of keys available in Ananthkrishnan and David (2004) and standard manuals.

\section{Statistical analysis}

The type of diversity used in the present investigation was $\dot{\alpha}$-diversity which is the diversity of species within a community. The diversity index was calculated by using Shannon - Wiener diversity index (Shannon Wiener, 1949)

\section{Shannon Wiener diversity index}

$\mathrm{H}=-\sum \mathrm{Pi} \ln \mathrm{Pi}$ Eq.1

Where $\mathrm{Pi}=\mathrm{S} / \mathrm{N}$

$\mathrm{S}=$ number of species

$\mathrm{N}=$ total number of individuals

In=logarithm of base e

\section{Measurement of species richness}

Margalef's index was used to measure the species richness (Margalef, 1958)

Margalef's index $=(\mathrm{S}-1) / \mathrm{ln} \mathrm{N}$

$\mathrm{S}=$ total number of species

$\mathrm{N}=$ total number of individuals in sample

$\mathrm{In}=$ logarithm of base $\mathrm{e}$

\section{RESULTS AND DISCUSSION}

The observation of insect pollinators on Ridge gourd $L$. acutangula revealed the absence of diurnal pollinators as flowers of ridge gourd started blooming in the evening at $17.00 \mathrm{~h}$. The flowers were visited by nocturnal insects. A total of 830 insect pollinators were sampled from June 2020 to November 2020. Altogether 17 species of insect pollinators belonging to 7 families under 6 orders have been recorded in Table 1 and the photographs of all the recorded nocturnal pollinators species on ridge gourd are given in Fig. 2.

Among the total number of species, the Lepidoptera was the dominant order comprising 11 species belonging to the single family Crambidae. The species were Spoladea recurvalis, Diaphnia hyalinata, Hydridids ornatalis ,Glyphodes bicolor, Pycnormon cribata , Paraponyx villidalis, Botyodes asialism, Chabula acamasalis, Poliobotys albactis, Parotis marginata , , Elophila sps; followed by the order Blattodea comprising 2 species belonging to 2 families; Loboptera decipiens , Periplaneta americana. Hymenoptera comprised 1 species belonging to family Formicidae that was Mon- 


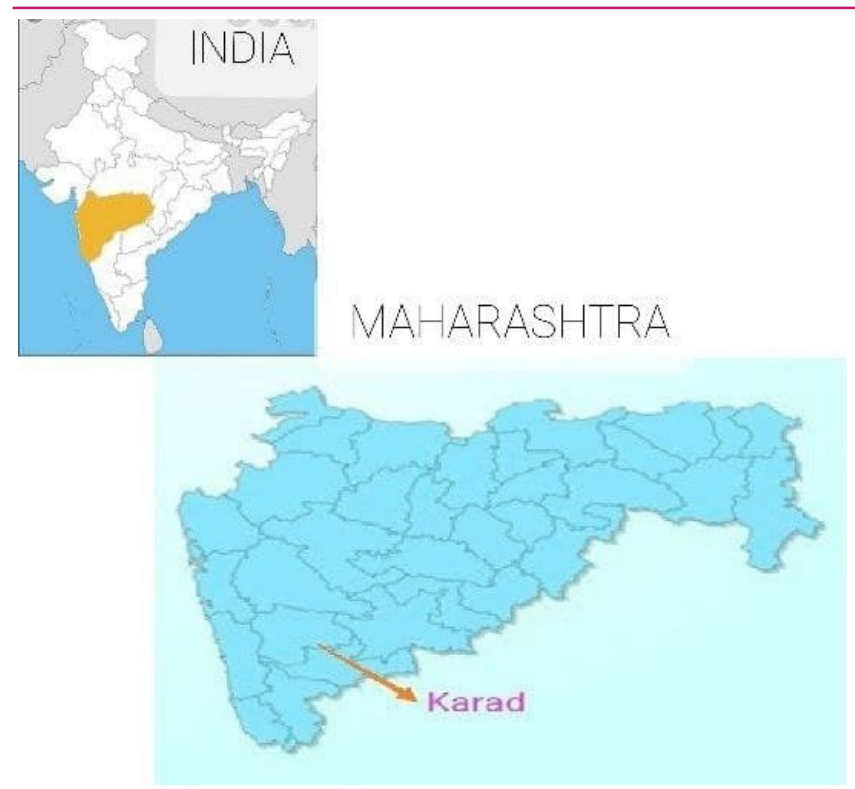

Fig.1. Location map of Karad tehsil.

omorium minimum. It was followed by order Orthoptera comprising 1 species Gryllus personatus belonging to family Gryllidae that was followed by order Diptera comprising 1 species Culex pilosus belonging the Family Culicidae, followed by the order Coleoptera comprising 1 species Gastrophysa viridula belonging to the family Chrysomelidae .

The above findings are in consent with the results of prior workers who also reported different insect pollinators of ridge gourd and cucurbits. Nocturnal pollinators strongly contribute to pollen transport of different agricultural crops. Predominantly moths visit flowers to obtain nectar, which is an strenuous food source and the main adult food source in the majority of moth species
(Willmer, 2011).

The pollinator diversity and abundance in major cucurbitaceous crops have been studied by Subhakar and Sreedevi (2015) who recorded 11 insect species from eight families of five orders viz., seven lepidopterans comprised of six species amounting to $76.68 \%$, two orthopterans species comprising $7.92 \%$ and one species each from hymenoptera amounting to $7.33 \%$, coleopteran $7.60 \%$ and dictyoptera $6.20 \%$. Lepidopteran flower visitors constituted $76.68 \%$. Among these, Hippotion celerio and Diaphania indica were the most abundant and frequent visitors in ridge gourd and Glyphodes bivitralis Guenee on ridge gourd flowers were the specialist. In United Kingdom in Nortflok eastern England, near villages of Bodham and Briston, Walton et al. (2020) recorded 103 moth species dominated by Family Noctuidae, Erebidae and Geometridae with 838 individuals swabbed, and 381 moth specimens $(45.5 \%)$ were found to transport pollen. From pollen transporting moths, $81 \%$ moth species carried more than one pollen grain, $30 \%$ carried between 2 and 5 pollen grains, $51 \% \geq 5$ pollen grains and $19 \% \geq 10$ pollen grains. Furthermore, $20 \%$ of moth species carried pollen arising from various plant species. Of the detected pollen grains, $57 \%$ were encountered on the under-thorax of the moths.

The bright colour of the ridge guard flowers is invisible to the insect in the dark when visual signals are of limited use. The nectar and pleasant scent produced by flowers attract and manipulate the nocturnal pollinators. (Andrews et al 2007,Jurgens et al2009,Riffell et al 2011) The nocturnal pollinators detect flower's scent and track the concentration gradient of chemicals which produces the scent of the flower (Borges et

Table 1. List of insect pollinators on Ridge gourd L. acutangula flowers at Karad.

\begin{tabular}{|c|c|c|c|c|}
\hline Sr No. & Insect Order & Family & Scientific Name & Total No. of individuals \\
\hline \multirow[t]{11}{*}{1.} & Lepidoptera & Crambidae & 1. Spoladea recurvalis & 49 \\
\hline & & & 2. Diaphnia hyalinata & 278 \\
\hline & & & 3. Hydridids ornatalis & 29 \\
\hline & & & 4. Glyphodes bicolor & 33 \\
\hline & & & 5. Pycnormon cribata & 50 \\
\hline & & & 6. Paraponyx villidalis & 16 \\
\hline & & & 7. Botyodes asialism & 7 \\
\hline & & & 8. Chabula acamasalis & 101 \\
\hline & & & 9. Poliobotys albactis & 29 \\
\hline & & & 10. Parotis marginata & 3 \\
\hline & & & 11. Elophila sps. & 5 \\
\hline 2. & Orthoptera & Gryllidae & 12. Gryllus personatus & 19 \\
\hline 3. & Diptera & Culicidae & 13. Culex pilosus & 56 \\
\hline 4. & Coleoptera & Chrysomelidae & 14. Gastrophysa viridula. & 11 \\
\hline \multirow[t]{2}{*}{5.} & Blattodea & Ectobiidae & 15. Loboptera decipiens & 26 \\
\hline & & Blattidae & 16. Periplaneta americana & 21 \\
\hline 6. & Hymenoptera & Formicidae & 17. Monomorium minimum & 97 \\
\hline
\end{tabular}



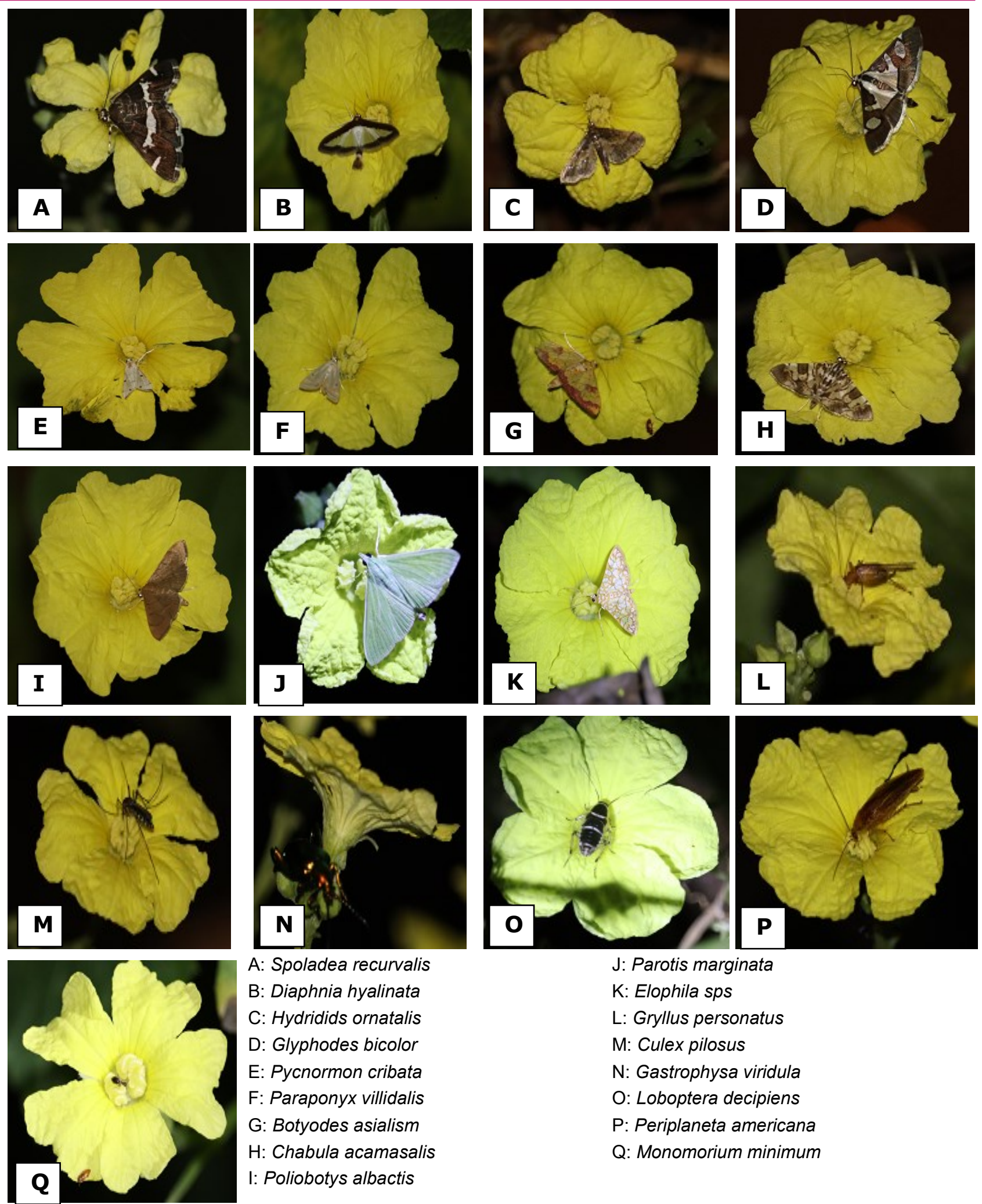

A: Spoladea recurvalis

B: Diaphnia hyalinata

$\mathrm{J}$ : Parotis marginata

$\mathrm{K}$ : Elophila sps

C: Hydridids ornatalis

L: Gryllus personatus

M: Culex pilosus

D: Glyphodes bicolor

$\mathrm{N}$ : Gastrophysa viridula

O: Loboptera decipiens

$\mathrm{F}$ : Paraponyx villidalis

G: Botyodes asialism

P: Periplaneta americana

$\mathrm{H}$ : Chabula acamasalis

Q: Monomorium minimum

$\mathrm{I}$ : Poliobotys albactis

Fig. 2. Photographs of nocturnal Insect Pollinator species on Ridge gourd.

al.2016). It showed olfaction has major role in pollination.Flowers render the landing platform for the insect to brush against anthers and stigma(Daniel et al 2020). Sourakov (2008) recorded producing scents ylangylang trees in Philippines compete for specialized night pollinators among which insects are the most common pollinators. The pollination biology of ridge gourd has been studied by Rame Gowda (2016), who recorded four species of Hymenoptera (28.15\%), seven species of Lepidoptera (50\%), two of Coleoptera (14.28\%) and one Diptera $(7.14 \%)$ visited ridge gourd flowers.

The abundance of the pollinators was considered as a 
single pollinator cannot transfer sufficient pollen to the stigmatic surface of a flower in one visit to allow for the development of a perfectly formed fruit. This study highlights that Lepidopteran species abundance was $72.28 \%$, Hymenopteran species abundance was $11.68 \%$, Orthopteran species was $2.28 \%$, Dipteran species abundance was $6.74 \%$, Coleopteran species abundance was $1.32 \%$, Blattodean species abundance was $5.66 \%$. Thus, each fruit-producing flower needs multiple pollinator visits. Which is supported by the several other workers that to obtain sufficient amounts of pollen grains on the stigma to set fruit needs multiple pollinators visits ( Stanghellini 2002,Vidal et al., 2010 ). The rise in number of visits per fruit-producing flower will result in cucurbit fruits having greater size, weight, sweetness, firmness, and more seeds (Hossain et al., 2018).

The diversity of nocturnal insect pollinators was calculated by Shannon-Wiener index and Species richness of pollinators calculated by Margalef's index is given in Table 2. This study highlights the richness of nocturnal insect pollinators on Ridge gourd, comprising 830 individuals belonging to the 17 species. The results showed that Lepidoptera was the most dominant species representing 600 individuals belonging to family Crambidae with 11 species. It was analysed that order Lepidoptera recorded the highest species richness (1.5632) and Shannon Wiener index (0.0733) and the order Coleoptera was the lowest order with the species richness (0.5829) and the Shannon Wiener index 0.2179 . The variation in species richness was due to variety of crops and microhabitats in surrounding of the field.

The present study showed that among all the species, Diaphnia hyalinata was the dominant species and showed less sensitivity to artificial light. Nocturnal insect species adapt to light after minute exposure to light (Walcott 1969) and show typical daytime behaviours such as cessation of movements and settling down. Artificial light has an influence on the sensitivity of the compound eyes of moths (Frank, 2006). In addition to compound eyes, most insects (including moths) have simple eyes (dorsal ocelli) that are sensitive to changes in light intensity (Mizunami, 1995) and appear to have a role in organizing flight initiation at dark in moths (Eaton et al., 1983). It is possible that artificial night lighting could delay or even prevent the onset of nocturnal activity. The visual capacity of moths could also be indirectly affected by artificial night lighting altering the spectrum of background illumination.Ultraviolet (UV) radiation (10-400 nm), mostly at longer wavelengths close to visible light (Eguchi et al., 1982), is important to pollinate moths, as moths comply themselves to flowers by a combination of olfactory and visual signals (Robert et al., 2005). It has been observed for many years that shorter wavelengths are more attractive to moths (Frank 2006). The spectral content of artificial lights will affect flower-visiting moths ( Davies et al.,2013). The rate of attraction and wavelength both vary between moth taxa (Merckx and Slade 2014)

The present study observed diverse insect pollinators were due to flower abundance and vegetation structure of the study area. Though the insect pollinators visited ridge gourd flowers for feeding, the surrounding vegetation might be supportive for the completion of their life cycle. Being nocturnal, they utilized nocturnal light for orientation, navigation, location of food, reproduction and avoidance of predators. The study area was less intensive of agricultural practices and light intensities from artificial sources were less, which proved good for insect diversity and population. Also, the pollinators could recognise and respond to environmental differences, which allowed them to exploit environmental heterogeneity.

\section{Conclusion}

The present investigation has revealed that the Ridge gourd flowers were visited by seventeen insect pollinator species belonging to the seven families of six orders. The lepidopterans were the diverse and major flower visitors by eliminating diversity, abundance and species richness of nocturnal pollinators on Ridge gourd. There was the existence of wide and rich pollinators on ridge gourd in Karad tehsil. The assessment

Table 2. Diversity indices for insect pollinators collected from ridge gourd field of Karad .

\begin{tabular}{lllllll}
\hline $\begin{array}{l}\text { Sr. } \\
\text { No. }\end{array}$ & Insect Order & $\begin{array}{l}\text { Total number } \\
\text { of families }\end{array}$ & $\begin{array}{l}\text { Total number } \\
\text { of species }\end{array}$ & $\begin{array}{l}\text { Total number of } \\
\text { individuals }\end{array}$ & $\begin{array}{l}\text { Margalef's } \\
\text { index }\end{array}$ & $\begin{array}{l}\text { Shannon-Wiener } \\
\text { index }\end{array}$ \\
\hline 1 & Lepidoptera & 1 & 11 & 600 & 1.5632 & 0.0733 \\
2 & Hymenoptera & 1 & 1 & 97 & 0.7814 & 0.0471 \\
3 & Orthoptera & 1 & 1 & 19 & 0.6603 & 0.1549 \\
4 & Diptera & 1 & 1 & 56 & 0.7515 & 0.0717 \\
5 & Coleoptera & 1 & 1 & 11 & 0.5829 & 0.2179 \\
6 & Blattodea & 2 & 2 & 47 & 1.4805 & 0.1342 \\
& Total & 7 & 17 & 830 & & \\
\hline
\end{tabular}


of ecological parameters affecting the life history of insect pollinators and the studies on larval host plants must be done to record moth host plants that are endemic to this region which will add a new record to host plant databases. The efforts should be made to conserve existing pollinators in agricultural farm and enhance their abundance and diversity as a provision for increased service demand.

\section{ACKNOWLEDGEMENTS}

We are thankful to the farmers that participated in this study; also we express our gratitude towards Miss. Pooja Pawar and Mr. Shubham Pawar for their assistance during field work We appreciate their help in handling light source and photography. This research was supported by the Chhatrapati Shahu Maharaj Research Training and Human Development Institute (SARATHI) Pune, Maharashtra.

\section{Conflict of interest}

The authors declare that they have no conflict of interest.

\section{REFERENCES}

1. Andrews E., Theis N. \& Adler L.(2007).Pollinator and Herbivore Attraction to Cucurbita Floral Volatiles. Journal of Chemical Ecology, 33,1682-1691.doi:10.1007/s10886-007 -9337-7. 2.Ananthkrishnan,T.N. \& David,B.V.(2004). General and Applied Entomology, Second edition. Tata McGraw Hill publishing company limited, New Delhi.

2. Borges ,R.M.,Somnathan,H.,\& Kelber,A.(2016).Patterns and processes in nocturnal and crepuscular pollination services. Q. Rev. Biol., 91,389-418.doi:10.1086/689481.

3. Christenhusz, M. J. M. \& Byng, J. W. (2016). The number of known plants species in the world and its annual increase. Phytotaxa, 261 (3),201-217. doi:10.11646/phytot axa.261.3.1

4. Davies,T.W., Bennie,J., Inger, R.,delbarra, N.H. \& Gaston,K.J.(2013). Artificial light pollution: Are shifting spectral signatures changing the balance of species interactions? Global Change Biology,19,1417-1423.

5. Delaplane, K.S. \& Mayer, D.F. (2000). Crop Pollination by Bees. Cambridge, U.K.: CABI, 344pp. doi:10.1079/97808 51994482.0000

6. Daniel,R.J., Johnson,S.D.,\& Peter C.I. (2020). Flower orientation in Glorisa superba (Colchicaceae) promotes cross-pollination via butterfly wings. Annals of Botany,125 (7),1137-1149.doi:10.1093/aob/mcaa048

7. Eaton J.L, Tignor K.R, Holtzman G.I.(1983). Role of moth ocelli in timing flight initiation at dusk.Physiol Entomol,8 (4),371-375.

8. Eguchi ,E.,Watanbe ,K.,Hariyama T.,Yamamoto K. (1982).A comparison of electrophysically determined spectral responses in 35 species of Lepidoptera. Journal of Insect Physiology, 28(8), 675-682.

9. Frank, K.D. (2006). Effects of artificial night light on moths. Ecological Consequences of Artificial Night Lighting (eds
C. Rich \& T. Longcore), pp.345-364. Washington, Island Press. . 11.Free, J.B. (1993). Insect Pollination of Crops. London, U.K.: Academic Press, 684pp.

10. Hossain,M.S.,Yeasmin F.,Rahman M.M.,Akhtar S.\& Hansat M.A.(2018).Role of insect visits on Cucumber (Cucumis sativus L.) yield. J. Biodivers. Conser. bioresources manage, 4(2), 81-87.DOI:http://doi.org/10.3329/ jbcbm.v4i2.39854

11. Jurgens A, Witt T.,\&Gottsberger G.(2002). Flower scent composition in night-flowering Silene species (Caryophyllaceae). Biochemical Systematics and Ecology. 30,383-397. doi:10.1016/S0305-1978(01)00106-5.

12. King,C.,Ballantyne,G\& Willmer,P.G.(2013).Why flower visitation is a poor proxy for pollination:measuring single visit pollen deposition, with implication for pollinaton networks and conservation. Methods in Ecology and Evolution, 4, 811-818.

13. Klein, A.M., Vaissière, B., Cane, J.H., Steffan-Dewenter, I., Cunningham, S.A., Kremer C.\& Tscharntcke, T. (2007). Importance of pollinators in changing landscapes for world crops. Proceedings of the Royal Society of London Biological Science, 274,303-313. http://doi.org/10.1098/ rspb.200 6.3721

14. Merckx, T,\& Slade,E.M.(2014).Macro moth families differ in their attraction to light: implications for light-trap monitoring programmes. Insect Conservation and Diversity,7,453-461.DOI:10.1111/icad.12068.

15. Margalef,R.,(1958).Temporal succession and spatial heterogeneity in phytoplankton.In :Perspectives in Marine biology, Buzzati-Traverso(ed.),Univ. Calif Press,Berke ley ,pp.323-347.

16. Mizunami M.(1995). Functional diversity of neural organizationin insect ocellar systems.Vision Res.:35(4),443452.Doi:10.1016/0042-6989(94)00192-o.

17. Nepi, M and Pacini, E (1993). Pollination, pollen viability and pistil receptivity in Cucurbita pepo.Annals of Botany, 72,527-536.doi:10.1006/anbo.1993.1141

18. Rame Gawda, K.N. Thesis.. Studies on pollination biology of ridge gourd (Luffa acutangula L.)2016, University of AgriculturalSciences,Bengaluru.URI:http://krishikosh.e granth.ac.in/handle/1/5810031170

19. Riffell J.A.,Shlizerman E,Sanders E,Abrell L,Medina B,Hinterwirth A.J.\&Kutz J.N.(2014).Flower discrimination by pollinators in a dynamic chemical environment. Science.344,1515-1518.doi:10.1126/science.12 51041.

20. Robert A , Raguso, Mark A Willis .(2005).Synergy between visual and olfactory cues in nectar feeding by wild hawkmoths, Manduca sexta. Animal behavior, 69(2),407418.http://doi.org/10.1016/j.anbehav.2004.04.015

21. Shannon,C.E., \& Wiener ,W.,(1949). The mathematical Theory of communication .Urbana: University of Illinois Press.

22. Stanghellini,M.S., Scultheis,J.R.\& Ambrose,J.T. (2002). Pollen mobilization in selected cucurbitaceae and the putative effects on pollinator abundance on pollen depletion rates. Journal of American Society for Horticultural Science,127,729-736.

23. Subhakar G. \& Shreedevi K (2015). Nocturnal insect pollinator diversity in bottle guard and ridge guard in southern AndhraPradesh. CurrentBiotica,9(2),137-144.

24. Sourakov A. (2008). Night Blooming Plants and Their Insect Pollinators. In: Capinera J.L. (eds) Encyclopedia of 
Patil, A. H. and Jagdale, S. / J. Appl. \& Nat. Sci. 13(2), 463 - 469 (2021)

Entomology. Springer, Dordrecht. https://doi.org/10.100 7/978-1-4020-6359-6_2220

25. Vidal, M.G., Jong D.,Wien H.C.\& Morse R.A.. (2010).Pollination and fruit set in pumpkin (Cucurbita pepo) by honey bees. Revista Brazil.Bot.,33(1):107-113 DOI:10.1590/S0100-84042010000100010.

26. Walcott B (1969). Movement of Retinula Cells in Insect Eyes on Light Adaptation .Nature ,223,971-972.http:// doi.org/10.1038/223971a0

27. Walton RE, Sayer CD, Bennion H.\& Axmacher JC. (2020). Nocturnal pollinators strongly contribute to pollen transport of wild flowers in an agricultural landscape. Biol. Lett. 20190877. http://dx.doi.org/10.1098/ rsbl.2019.0877

28. Willmer P.(2011). Pollination and Floral Ecology. Princeton, New Jersey: Princeton University Press. 